Paradigmatic uniformity and markedness ${ }^{1}$

\title{
Andrew Garrett
}

\section{Introduction}

Historical linguists traditionally distinguish extension and leveling as two important subtypes of analogical change. Extension is said to take place when an alternating pattern is introduced to a previously non-alternating paradigm (e.g. the irregular drivedrove alternation is extended in some English dialects to produce dive-dove); leveling is the elimination of paradigmatic alternations. A textbook case of leveling (Trask 1996: 109) is the transformation of the Old French paradigm of "love" as in (1); the modern forms cited show leveling of the stem alternation between aim- and am-.

1 sg. aim 1 pl. amons $\rightarrow$ Modern French aimons

2 sg. aimes 2 pl. amez $\rightarrow$ Modern French aimez

3 sg. aimet 3 pl. aiment

Patterns of extension and leveling have been a testing ground for linguistic theories since the beginning of scientific linguistics (Verner 1875, Paul 1880).

In this chapter I survey a set of levelings and extensions affecting verb paradigms in two languages, English and Ancient Greek. While most of the individual changes are well described in the literature, two broader patterns have gone unnoticed. I will suggest that one pattern, shared by English and Greek, is a diachronic universal; the other sharply distinguishes Greek from English. Each pattern in turn helps answer one of the questions posed in (2a-b).

(2) a. Optimization. Does paradigm leveling occur because of some optimizing impulse (a preference for simplicity in general or uniform paradigms in particular) or, alternatively, is it a consequence of independent mechanisms of morphological change?

b. Directionality. In cases of paradigm leveling, where one alternant (e.g. stem allomorph) replaces another, what principles explain the directionality of

\footnotetext{
${ }^{1}$ For discussion and comments on early versions of this chapter I am grateful to Adam Albright, Stephen Colvin, Susanne Gahl, Jeff Good, Larry Hyman, Sharon Inkelas, Theresa McFarland, Anna Morpurgo Davies, Pawel Nowak, Calvert Watkins, three anonymous referees, and audiences at Berkeley, Harvard, and Oxford.
} 
leveling? Why is one alternant generalized while another is replaced? These are crucial questions for any account of paradigm structure and diachrony. ${ }^{2}$

The optimization question in (2a) bears directly on the theme of this volume. In numerous languages many paradigms are non-alternating; language change often transforms alternating paradigms into non-alternating ones. Why are such patterns common? Do they reflect an innate preference for uniformity, one that somehow guides change and is grounded in universal principles of language or psychology, or do they have another explanation? In linguistic theory the innate preference view has been reified under various names (Paradigm Coherence, Output-Output Correspondence, Uniform Exponence, etc.), but all such approaches posit distinct forces or constraints favoring uniformity. ${ }^{3}$ The same view is also common in historical linguistics: 'The motivation for leveling has been plausibly expressed in the slogan ONE MEANING - ONE FORM' (Hock \& Joseph 1996: 155, following Hock 1991: 168).

I will argue, against this view, that there is no innate drive toward uniformity and that paradigm leveling is a by-product of independently motivated mechanisms of morphological change. Specifically, uniformity arises when the pattern of a nonalternating paradigm is imposed on a formerly alternating paradigm; it is in effect a type of extension. My argument is thus an "evolutionary" one in the sense of Blevins \& Garrett (2004) and Blevins (2004). ${ }^{4}$

The directionality questions in (2b) are also important for our understanding of

\footnotetext{
${ }^{2}$ I will not address a third crucial question, selectivity: Why, under apparently similar circumstances, are alternations in one paradigm leveled while those in another paradigm are not? See Garrett (2007).

${ }^{3}$ See e.g. Kiparsky (1972), Burzio (1996, 2000), Buckley (1999), Kenstowicz (1996), Benua (2000), Steriade (1999, 2000), and McCarthy (2005).

${ }^{4}$ The "evolution" metaphor has had other uses in language change (Haspelmath 1999a, Croft 2000, McMahon 2000), and I will generally avoid it. But analyses along broadly similar lines are available for a range of patterns: in syntax and morphosyntax, for split ergative case marking (Anderson 1977, Garrett 1990a), preposition-verb compounding (Garrett 1990b), adposition placement (Aristar 1991), and article-possessor complementarity (Haspelmath 1999b); in phonology, for dissimilation (Ohala 1981, 1993), velar palatalization (Guion 1998), metathesis (Blevins \& Garrett 1998, 2004), compensatory lengthening (Kavitskaya 2002), antigemination (Blevins 2005), positional vowel quality neutralization (Barnes 2006), consonant epenthesis (Blevins this volume), and other patterns (Blevins 2004); in morphology, for infixation (Garrett 2001, Yu 2003) and templatic constructions (Good 2003); and in semantics and syntax, for numerous categories (e.g. Bybee 1988, Bybee et al. 1994). Looming over the whole field is the work of scholars like Baudouin de Courtenay and Greenberg.
} 
paradigm structure, and they relate to a second theme of this chapter: markedness. Leveling shows persistent regularities in directionality - singulars tend to replace plurals, nominatives tend to replace non-nominatives, third-person verb forms tend to replace first- and second-person forms, etc. - but there are exceptions and the reasons for the patterns remain unclear. Sometimes the patterns are associated with "markedness" - singulars are said to be unmarked vis-à-vis plurals, etc. — so if we can understand directionality in leveling we may come to understand the basis of markedness. ${ }^{5}$ This too bears on the theme of the present volume: if knowledge of some markedness patterns were innate, then directionality effects in leveling would be a manifestation of universal grammar. I will argue to the contrary that markedness patterns, as they emerge in paradigm leveling, are a product of the meaning and usage of the relevant categories.

I will address the questions in (2a-b) through an analysis of changes affecting a well-defined part of the morphology of two languages, English and Ancient Greek. Specifically, I will look at changes in present vs. non-present verbal stem formation. The verbal systems of the two languages are organized along lines that are partly similar, partly different; the similarities and differences are both relevant. English has a basic opposition between present and preterite stems, which may be different (as in the drivedrove case above) or identical (as in standard dive-dived). Ancient Greek has an opposition between present (aspectually imperfective) and aorist (perfective) stems; a third basic category is the perfect. In both languages I will examine cases where alternations between present and nonpresent (English preterite, Greek aorist) stems were leveled, as well as cases where extension yielded alternations in previously non-alternating paradigms. My goal is to give a comprehensive picture of patterns of stem leveling and extension in the two languages.

The method I use is novel and yields new results. In studies of the optimization and directionality questions, the usual method is to analyze selected cases. These may be parade examples, such as the leveling of Latin rhotacism, or other cases where only an innate impulse toward uniformity seems to explain leveling. Such studies are essential,

\footnotetext{
${ }^{5}$ I share Haspelmath's (2006) reservations about the term "markedness", though obviously (contrary to his recommendation) I use the term here. What he calls "semantic markedness" is the specific type under discussion; in §4 I also argue that there is a relation between formal and semantic markedness.
} 
but the overall pattern of leveling and extension in a language also reveals generalizations that have not emerged from the study of individual cases.

In addressing the optimization question, the innate preference view of paradigm uniformity and the view I will sketch make different predictions about a language's overall dossier of levelings. I will argue that leveling is a special case of extension in which a non-alternating pattern is extended to a previously alternating paradigm. This requires that a suitable non-alternating model paradigm can be identified for every case of leveling. The innate preference view makes no such prediction; rather, since leveling is driven simply by a force favoring uniformity, it should be possible even without a non-alternating model paradigm. These predictions can be tested on a sufficiently rich dossier of examples. The facts turn out to contradict the innate preference view and to support the view that leveling is just extension.

In addressing the directionality question, my focus will be on a language-specific class of exceptions to an otherwise robust typological generalization. Exceptions to typological patterns, such as replacement of nominative by non-nominative forms, are usually assumed to be revealing (Tiersma 1982; Albright 2003, 2005, this volume). In this case the typologically widespread pattern is that presents are generalized at the expense of non-presents, and the systematic exception is in Ancient Greek. I will show that the Greek facts fit comfortably into no current theory of directionality but that they may be explained by a meaning-based account along lines first suggested by Kuryłowicz (1945-49).

The remainder of this chapter is organized as follows. I discuss the basic English and Ancient Greek data in §§2-3 respectively. In §4 I address the implications of the Greek data for the directionality question, and in \$5 I summarize and conclude. But first, I will very briefly sketch my assumptions about morphological change.

I assume that morphological production involves competition between the retrieval of memorized forms and the creation of new ones by rule, and that a mechanism of change is the creation of new forms if existing ones are not learned, remembered, or accessed fast enough (Bybee 1985, Barr 1994). This may have several causes. Learners may not hear an existing form, for instance, or they may hear it too infrequently to learn it. Alternatively, a morphological rule may be so salient that a new form is produced despite the existence of a memorized one; I will return to "salience" in $§ 4$. In any 
case, sometimes an existing form is not reproduced and is replaced by a new form generated by rule. If this catches on, the older form may become otiose in a speech community and the newer form may replace it.

\section{$2 \quad$ Middle and Modern English}

English verbs are traditionally classified as strong or weak. Strong verbs have an unsuffixed preterite (i.e. past-tense form) and include various classes defined by their ablaut patterns; examples include drive-drove and sing-sang. ${ }^{6}$ Weak verbs have suffixed preterites (e.g. with -ed) and fall into the three historical classes in (4), the last of which has several subtypes.

(4) English weak verb classes

a. Regular weak verbs: no stem alternations (e.g. like-liked, play-played)

b. Rückumlaut weak verbs: stem alternations due to earlier present-stem umlaut (e.g. buy-bought) ${ }^{7}$

c. "Irregular" weak verbs:

i. Stem alternations due to preterite-stem vowel shortening (e.g. keepkept)

ii. Stem alternations due to preterite suffix-vowel syncope (e.g. hit-hit)

iii. Combinations and extensions of i-ii (e.g. slide-slid, bend-bent)

Various types of extension and leveling occur. ${ }^{8}$

The most frequent type of change, of course, is transfer from the strong class or an irregular weak class into the large class of regular weak verbs. Representative strong verbs that have undergone this change are bake and help, whose Old English preterites bóc and healp were replaced by baked and helped in the Middle English period. A representative irregular weak verb that has become regular is reap, whose seventeenth- and

\footnotetext{
${ }^{6}$ Here I mainly ignore the third principal part, the participle (e.g. driven, sung). An analysis of the role of participles would be essential for a full understanding of changes in English verb stem formation, but it would not affect my general argument.

${ }^{7}$ The term Rückumlaut ('back umlaut') alludes to the fact that umlaut affected present stem forms in these verbs.

${ }^{8}$ The changes discussed below are individually well known; for further information see the standard historical grammars (especially Jespersen 1942 and Luick 1914-1940) and grammatical surveys (e.g. Mossé 1968). Note that the $b$ ('thorn') symbol writes an interdental fricative in Old English forms.
} 
eighteenth-century preterite reapt [rept] has been replaced by the regular weak form reaped. ${ }^{9}$ All transfers of this frequent type have the effect of leveling - loss of a stem alternation - but can also be analyzed as extensions in which the morphological rule for regular weak verbs is applied to new items.

Rückumlaut weak verbs too have been transferred to the regular weak class. In Northern Middle English (Krygier 1997: 245-253), for example, duell "dwell”, quell "kill", quak "quake", and wach "watch" show only regular weak preterites duelled, queld, quaked, and wachit, not the historically expected *dwald, *cwald, *quahte, and "wahte. Some other Rückumlaut verbs (e.g. reche "reach", teche "teach", tell "tell") vary between regular weak forms (reched, teched, teld) and the historically expected forms (raht, taht, tald). ${ }^{10}$ Here too transfer has the effect of leveling (dwell-dwald $\rightarrow$ dwelldwelled), but it also amounts to extension of the non-alternating pattern of regular weak verbs.

Transfers into the irregular weak verb subclass in (4cii) could also be regarded as leveling. A representative case is burst, whose original strong preterite survives as Middle English barst but was replaced by burst beginning in the sixteenth century. (It is also transferred into the regular weak class as bursted or busted.) This is an extension of the pattern of set, shut, and other verbs properly belonging to the subclass in (4cii).

Transfers with the effect of leveling are common in the history of English verb inflection. But transfers also produce disuniformity. In Middle English (Marckwardt 1935), for example, the pattern of verbs like $3 \mathrm{sg}$. present mynt "thinks", preterite mynte was extended to $3 \mathrm{sg}$. present sent "sends", preterite sende, yielding a new $3 \mathrm{sg}$. preterite sente and other forms based on a new preterite stem sent-. From this point stem-final preterite devoicing was extended to the class of gyrden "gird" (girt), wenden "wend" (went), spildan "spill" (spilt), etc., with stem-final sonorant $+d$ clusters, and then to leave-left, mean-meant, etc.

A similar case is the creation of new irregular weak preterites formed on the model of bleed-bled, chide-chid, greet-gret, etc., with vowel "shortening" (quality change) in a stem ending in $d$ or $t$. New present-preterite pairs of this type include bite-bit, plead-

\footnotetext{
${ }^{9}$ Irregular weak verb inflection is itself an innovation for reap, originally a strong verb (Old English preterite singular rap).

${ }^{10}$ Still others (e.g. buy-bought) retain the Rückumlaut alternation.
} 
pled, shoot-shot, slide-slid, and weed-wed. In some cases the new form replaces a strong preterite (e.g. slid, replacing slad) and in others a regular weak preterite (e.g. wed, sporadic in Modern English, vs. regular weeded).

Finally, sometimes a verb is transferred from a weak class to a strong class. For example, dig, sneak, stick, and string were originally regular weak verbs with preterites digged, sneaked, sticked, and stringed; the strong preterites dug, snuck, stuck, and strung are first attested in Modern English. ${ }^{11}$ Of course such changes cannot be classified as leveling (they produce non-uniform paradigms), and they always requires an alternating model.

From this survey several important points emerge. First, as Bybee (1985: 51) notes, "changes in English verbs always involve a substitution of the Present base for the Past base." For example, the reap-reapt [rspt] alternation was not leveled by backforming a new present †rep but by forming a new preterite reaped, and the dwell-dwald alternation was not leveled by backforming a new present $\dagger d w a l$. I will return to the significance of this point in $\S 4$.

Second, in every case, a change in preterite stem formation involved the transfer of a verb into a pre-existing class - in other words, extension of an existing pattern. Usually the non-alternating pattern of regular weak verbs was extended to formerly irregular verbs, but in other cases an existing strong or irregular weak pattern was extended to a formerly regular verb. The point is that each change can be treated as extension.

Third, in 900 years of Middle and Modern English linguistic history, there was never any case of pure leveling. The vast majority of preterite stem changes yielded paradigm uniformity, to be sure, but only given a preexisting uniform paradigm of the same type. If a drive for uniformity were truly an independent force in language

\footnotetext{
${ }^{11}$ At least for dig and string, interestingly, the strong forms were attested first as participles and only somewhat later as preterites. As for sneak, the earliest example of snuck in the online Oxford English Dictionary corpus (dictionary.oed.com) is from 1887 and most examples are American. The same corpus has almost 20 examples of preterite sneaked from before 1900, including two from the seventeenth century; the OED editors' assertion that snuck is the original preterite form is therefore false. (Other OED entry details can now also be corrected with data from the Literature Online corpus, lion.chadwyck.com. The verb sneak is first attested in John Studley's 1581 translation of Seneca's Medea, i.e. 20 years before the first example in OED s.v. sneak, from Shakespeare. The adjectival participle sneaking is first attested in a 1576 volume by George Whetstone, The Rocke of Regarde, 14 years before the first example in OED s.v. sneaking ppl. a.).
} 
change, we would expect some cases in which uniformity is the sole motivation. For example, we might imagine that the Early Middle English paradigm of "drive" could have been transformed as in (5), with present-preterite ablaut leveled.

(5) Early Middle English "drive"

a. Present 1 sg. drive, 2 sg. drivest, 3 sg. driveb, plur. drivep

b. Preterite $1 \mathrm{sg}$. draf, $2 \mathrm{sg}$. drive, 3 sg. draf, plur. driven

c. Hypothetical new preterite via leveling (present stem + preterite endings):

1 sg. $\dagger d r i v, 2$ sg. †drive, 3 sg. †driv, pl. †drīven

The result of this hypothetical change would have been perfectly functional (e.g. 1 sg. present drive vs. preterite $\dagger d r i v$ ), but no such change happened. The significant difference between this hypothetical change and the actual pattern of changes is that all the actual changes can be regarded as extension, in traditional terms, or the application of a morphological rule to new items. By contrast, in (5), no pre-existing paradigm existed - for example a strong verb pattern lacking ablaut - that could have produced the new preterites. There simply was no basis for an extension.

An apparent case of leveling that should be noted because it is well known involves Verner's Law alternations in Old and Middle English. This is sometimes described as partial leveling, but it too is actually extension. A representative example is found in the Class II strong verbs, whose four Old English principal parts pattern as shown in $(6 a-c)$.

$\begin{array}{rlllll} & \text { Infinitive } & \text { Past 1sg/3sg } & \text { Past plural } & \text { Participle } & \\ \text { a. } & \text { bēodan } & \text { bēad } & \text { budon } & \text { boden } & \text { "command" } \\ \text { b. } & \text { cēosan } & \text { cēas } & \text { curon } & \text { coren } & \text { "choose" } \\ & \text { sēopan } & \text { sēap } & \text { sudon } & \text { soden } & \text { "boil" } \\ \text { c. } & \text { abrēopan } & \text { abrēap } & \text { abrupon } & \text { abropen } & \text { "fail" }\end{array}$

The example in (6a) is one of many verbs showing the regular ablaut pattern of Class II; those in (6b) are two of the six Class II strong verbs also showing consonant alternations, e.g. between $s$ and $r$ or $b$ and $d$, originally caused by Verner's Law. ${ }^{12}$ The example in (6c) originally had Verner's Law consonant alternations as in (6b), but in Old English

\footnotetext{
${ }^{12}$ Verner's Law was an accentually conditioned fricative voicing change, transformed by later changes into alternations like those seen in (6b); the four other verbs like cēosan and sēopan are drēosan "fall", forlēosan "lose", frēosan "freeze", and hrēosan "fall".
} 
they had already been leveled, resulting in invariant root-final $p$. This change also later affected some verbs like "choose" in (6b); modern English retains ablaut (choose-chose) but has eliminated the stem alternant with $r$. But this apparent case of leveling is easily explained as extension: the majority Class II pattern of bēodan in (6a), with ablaut but no consonant alternation, was extended to the minority with a consonant alternation. ${ }^{13}$ Leveling is not an explanation or a driving force in this change.

More broadly, I take it that a theory that predicts the possibility of changes of a sort that never materialize in nearly a millennium of paradigmatic reshufflings - levelings that cannot be analyzed as extensions - is not a very good theory. I conclude that paradigm uniformity is not a force in change, even where it may result from change. Instead, uniformity arises by extension of a non-alternating pattern to previously alternating paradigms. In $\S 3$ I will show that the same generalization holds for changes in Ancient Greek, but that Greek differs from English in the directionality of its presentnonpresent extensions and levelings.

\section{Ancient Greek}

There are four major tense/aspect categories in Ancient Greek: the present (including also the imperfect), expressing imperfective aspect; the aorist, expressing perfective aspect; the perfect (including also the pluperfect and future perfect); and the future. Here I will examine changes in the formation of present vs. aorist stems; the perfect and future stems will play almost no role in the discussion. I will show, first, as shown for English in §2, that while leveling leading to paradigm uniformity is common it can always be analyzed as extension and, second, that the directionality of paradigmatic changes in Ancient Greek is systematically different from that in English. I will suggest an analysis of the latter result in $\S 4 .^{14}$

The remainder of this section is divided into 5 sub-sections: in $\$ 3.1 \mathrm{I}$ provide an overview of the relevant stem formation patterns; in $\$ 3.2$ I discuss changes affecting thematic presents in ${ }^{*}-y$-; in $\S 3.3$ I discuss changes affecting nasal presents; in $\S 3.4$ I

\footnotetext{
${ }^{13}$ Similar accounts can be given of Verner's Law levelings in Classes I, III, and V.

${ }^{14}$ Individually the changes discussed here are well known; for presentations of the data with references to additional literature see Schwyzer (1953) and Meier-Brügger (1992). I have derived my database of Greek changes from these handbooks and from other standard references cited by them.
} 
discuss two apparent counterexamples to my claims about directionality; and I give a brief summary in $§ 3.5$.

\subsection{Present and aorist stem formation}

Ancient Greek had numerous present stem types. They can be classified as athematic or thematic according to whether there is a theme vowel between the stem and ending; thematic and athematic presents also have different inflectional endings. For example, the athematic $1 \mathrm{sg}$. indicative ending is -mi (deiknümi "I show" from stem deiknü-) while its thematic counterpart is - $\bar{o}$ (basiléuō "I am king"). I will cite verbs by stem rather than as fully inflected forms, and I will cite the theme vowel as -o-; the present stem of "be king" is thus basileu-o-. ${ }^{15}$

A summary of major athematic and thematic present stem classes is given in (7). The main athematic types are in (7a). Thematic types are listed in (7b), and include simple presents, nasal presents, and presents derived with a suffix *-y-. The *-y- suffix is lost phonologically due to prehistoric sound changes, with the three subtypes in (7biii).

(7) Major Ancient Greek present stem classes

a. Athematic: no theme vowel

i. Simple presents (e.g. ei-mí "I am" from root ei-)

ii. Nasal presents, with suffix $-n \bar{a}-(-n \bar{e}-$ in the Attic dialect) or $-(n) n \bar{u}-$

b. Thematic: theme vowel before inflectional endings

i. Simple presents

ii. Nasal presents (suffix -an-, with nasal infix in light roots, i.e. roots ending in a short vowel and one consonant)

iii. Suffix *-y- (always lost phonologically)

$\alpha$. Suffix *-y- preceded by a consonant (triggering various changes)

$\beta$. "Contract verbs" (suffix *-y- preceded by a short vowel)

$\gamma$. Verbs in *-eu-y- (denominative to noun stems in *-eu-)

There are two main types of aorist formation: the non-sigmatic aorist, usually formed via root ablaut; and the sigmatic aorist, formed with a suffix -s- added to the

\footnotetext{
${ }^{15}$ Citation by stem has the advantage of abstracting away from irrelevant morphophonemic changes. The theme vowel alternates between -o- (e.g. 1 sg.) and -e- (e.g. 2 sg., 3 sg.); I write -o- for expository convenience.
} 
present stem. (This suffix usually also has some effect on a preceding consonant). The sigmatic aorists are productive, analogous to the English weak preterites; the asigmatic aorists are analogous to the English strong preterites. Aorists also have a prefix $e$-called the 'augment'. For example, the aorist stem of the verb "be king" is e-basileu-s- $(1 \mathrm{sg}$. ebasileusa).

The largest present and aorist classes are the thematic presents and sigmatic aorists, but despite some subregularities there is no generally predictable relationship between the type of present stem a given verb has and the type of aorist stem it has. In virtually all present classes some verbs form sigmatic aorists, for example, but on the other hand some sigmatic aorists and some asigmatic aorists correspond to thematic presents.

\subsection{Thematic presents in $*-y-$}

The loss of *y with attendant effects on adjacent consonants led to opaque relationships betwen present and aorist stems in several subcategories of thematic present in *-y-. In turn a number of paradigmatic shifts can be attributed to these opaque relationships.

First, several transfers effectively shifted verbs into the class of vowel-final stems in (8), themselves a mix of historical s-stems (e.g. "teles- "finish") and long-vowel stems (e.g. lū-o- "loose").

$\begin{array}{lll}\text { Aorist stem } & \text { Present stem } & \\ \text { e-tele-s- } & \text { tele-o- } & \text { "finish" } \\ \text { e-lū-s- } & \text { lū-o- } & \text { "loose" }\end{array}$

For example, the class of historical eu-stem verbs developed presents in -ei-o- (< ${ }^{*}-e u-y$-, i.e. $\left.{ }^{*}-e w-y-\right)$ alternating with aorists in -eu-s-. As seen in (9), that alternation was leveled in favor of the aorist. (Arrows here and below indicate analogical rebuilding.)

$$
\begin{array}{llll}
\text { Aorist stem } & \text { Earlier present stem } & \text { New present stem } & \\
\text { e-basileu-s- } & \text { *basilei-o- } & \rightarrow \text { basileu-o- } & \text { "be king" } \\
\text { e-douleu-s- } & \text { *doulei-o- } & \rightarrow \text { douleu-o- } & \text { "be a slave" } \\
\text { e-paideu-s- } & \text { *paidei-o- } & \rightarrow \text { paideu-o- } & \text { "be a child" }
\end{array}
$$

Likewise, as illustrated in (10), an alternation between long and short vowels in socalled "contract" verbs was leveled in favor of the aorist in various dialects of Greek. 
(10)

$$
\begin{array}{llll}
\text { Aorist stem } & \text { Earlier present stem } & \text { New present stem } & \\
\text { e-doulō-s- } & \text { doulo-o- } & \rightarrow \text { doulō-o- } & \text { "enslave" } \\
\text { e-poiē-s- } & \text { poie-o- } & \rightarrow \text { poiē-o- } & \text { "make, do" } \\
\text { e-step }{ }^{\text {hanō-s- }} & \text { step }^{\text {hano-o- }} & \rightarrow \text { step }^{\text {hanō-o- }} & \text { "crown" }
\end{array}
$$

Significantly, in neither case did leveling favor the present stem; for example, the aorist $e$-basileu-s- in (9) was not replaced by †e-basilei-s-, and the aorist $e$-doulō-s- in (10) was not replaced by te-doulo-s-.

Second, Proto-Greek $* k^{w(h)},{ }^{*} g^{w}$ underwent a conditioned split, creating alternations between aorist stems in $-p s-\left(<{ }^{*}-k^{w}-s-\right)$ and present stems in - sso- $\left(<*^{*}-k y o-<\right.$ $\left.{ }^{*}-k^{w}-y-o-\right)$ or $-z d o-\left(\right.$ from $\left.{ }^{*}-g y o-<*^{*}-g^{w}-y-o-\right)$. These alternations were leveled on the model of originally labial-final verbs (present stem in $-p t o-<{ }^{*}-p-y-o-$ ), like those in (11a); the result of leveling is shown in (11b).

(11) a. Aorist stem Present stem

$\begin{array}{lll}\text { e-blap-s- } & \text { blap-t-o- } & \text { "injure" } \\ \text { e-kop-s- } & \text { kop-t-o- } & \text { "cut" }\end{array}$

b. Aorist stem Earlier present stem New present stem

$\begin{array}{llll}\text { e-nip-s- } & \text { nizd-o- } & \rightarrow \text { nip-t-o- } & \text { "wash" } \\ \text { e-pep-s- } & \text { pess-o- } & \rightarrow \text { pep-t-o- } & \text { "cook" }\end{array}$

Significantly, again, it was the aorist rather than the present stem that served as the base in leveling.

Two final examples show extension rather than leveling. First, because Proto-Greek $* k y>t t$ in the Attic dialect, thematic presents in *-y-o- with roots ending in $k$ show a regular alternation between aorist stems in -ks- and present stems in -tt-o-; see (12a). In Attic, as shown in (12b), the alternation in (12a) was extended to other verbs with aorist stems in $-k s$ - from roots ending in $g$; they had originally had present stems in *-zd-o- $(<*$-gy-o- $) .{ }^{16}$

\footnotetext{
${ }^{16}$ In the same dialect, leveling goes the other way in one case: the present stem harpazd-o- "snatch away" spawned a new aorist stem hèrpas- (/e-harpad-s-/) next to older hērpaks-. I cannot explain why this verb goes against the general pattern of the Attic dialect.
} 
(12) a. Aorist stem Present stem

$\begin{array}{lll}\text { e-tarak-s- } & \text { taratt-o- } & \text { "disturb" } \\ \text { e-p phulak-s- } & \text { p }^{\text {h}} \text { ulatt-o- } & \text { "guard" } \\ \text { e-pharmak-s- } & \text { p }^{\text {h}} \text { armatt-o- } & \text { "treat with drugs" }\end{array}$

b. Aorist stem Earlier present stem New present stem

$\begin{array}{llll}\begin{array}{l}\text { ellak-s- } \\ \text { (/e-allak-s-/) }\end{array} & \text { *allazd-o- } & \text { allatt-o- } & \text { "(ex)change" } \\ \text { e-prak-s- } & \text { *prazd-o- } & \text { pratt-o- } & \text { "do" } \\ \text { e-sak-s- } & \text { *sazd-o- } & \text { satt-o- } & \text { "fill full" } \\ \text { e-sp"ak-s- } & \text { spphazd-o- } & \text { sphatt-o- } & \text { "slay" } \\ \text { e-tak-s- } & \text { *tazd-o- } & \text { tatt-o- } & \text { "put in order" }\end{array}$

Second, because Proto-Greek *ty $>$ tt but *ts $>s$, the Attic dialect had a pattern whereby aorist stems like e-plas- "form, mould" corresponded to present stems like platt-. This pattern was extended to one verb, given in (13), with an original aorist stem in $s$ and a present stem in $-z d-o-\left(<{ }^{*}-g-y-o-\right) .{ }^{17}$

$$
\begin{array}{lll}
\text { Aorist stem } & \text { Earlier present stem } & \text { New present stem } \\
\text { hērmos- (/e-harmo-s-/) } & \text { harmozd-o- } & \rightarrow \text { harmott-o- "adapt, fit" }
\end{array}
$$

In the cases discussed in this section, note again that it is the aorist stem that serves as the base of leveling or extension, not the present stem, and that all examples of leveling can be analyzed as extension of a uniform pattern.

\subsection{Nasal presents}

I turn next to nasal presents: verbs whose present stems are marked by suffixes with a nasal consonant. They show several patterns of leveling. Shown in (14-15) are verbs with the suffix $-n \bar{a}-(=-n \bar{e}$ - in the Attic dialect). Some verbs of this type acquired new presents in $-n n \bar{u}-$, as shown in (14b), while a few others acquired presents in $-z d-$, as in (15b). It is crucial that the aorist stems of all types were marked simply by -s-; the pattern in (14a) was extended as in (14b), and the pattern in (15a) was extended as in (15b).

\footnotetext{
${ }^{17}$ The aorist stem in (13) is underlyingly /e-harmod-s-/; cf. harmódios "fitting".
} 
(14) a. Aorist stem

Present stem

e-sbe-s-

sbe-nnū-

"extinguish"

e-zdō-s-

zdō-nnū-

"gird"

ēmphi-e-s- (/e-amphi-e-s-/)

amphi-e-nnū-

"clothe"

b. Aorist stem Earlier present stem New present stem

$\begin{array}{llll}\text { e-kera-s- } & \text { kir-nē- } & \rightarrow \text { kera-nnū- } & \text { "mix" } \\ \text { e-krema-s- } & \text { krim-nē- } & \rightarrow \text { krema-nnū- } & \text { "hang" } \\ \text { e-peta-s- } & \text { pit-nē- } & \rightarrow \text { peta-nnū- } & \text { "spread" } \\ \text { e-skeda-s- } & \text { skid-nē- } & \rightarrow \text { skeda-nnū- } & \text { "scatter" }\end{array}$

(15) a. Aorist stem Present stem

e-dika-s- dika-zd-o- "judge"

e-p ${ }^{\mathrm{h}}$ ra-s- $\quad \mathrm{p}^{\mathrm{h}}$ ra-zd-o- $\quad$ "tell"

b. Aorist stem Earlier present stem New present stem

$\begin{array}{llll}\text { e-dama-s- } & \text { dam-nē- } & \rightarrow \text { dama-zd-o- } & \text { "tame" } \\ \text { e-pela-s- } & \text { pil-nā- } & \rightarrow \text { pela-zd-o- } & \text { "approach" }\end{array}$

Significantly, again, it was the aorist that served as a pivot. The aorist stem e-peta-s- in (14b) could imaginably have been replaced by te-pitne-s- based on the present stem, and e-dama-s- in (15b) could have been replaced by te-damne-s-, but this did not happen.

Verbs in - $n$-C-an- are illustrated in (16). Some details are obscure (Schwyzer 1953: 699-701), but the pattern is robust and clearly relies on an aorist pivot. We do not know for sure precisely which of the verbs in (16) were the source of the pattern, but evidently it was extended from examples where the nasal 'infix' belonged to the root.

\begin{tabular}{|c|c|c|c|}
\hline Aorist stem & Earlier present stem & New present stem & \\
\hline e-dak- & dakn-o- & $\rightarrow$ dayk-an-o- & "bite" \\
\hline èrug- & ereug-o- & $\rightarrow$ eruyg-an-o- & "discharge" \\
\hline e-t $t^{\text {hig- }}$ & [none] & $\rightarrow \mathrm{t}^{\mathrm{h}}$ ung-an-o- & "touch" \\
\hline e-lab- & lazd-o- & $\rightarrow$ lamb-an-o- & "take" \\
\hline e-lat ${ }^{\mathrm{h}}$ & lēt $t^{\mathrm{h}} \mathrm{o}-$ & $\rightarrow$ lant $\mathrm{t}^{\mathrm{h}}$-an-o- & "escape notice" \\
\hline e-lak ${ }^{\mathrm{h}}-$ & [none] & $\rightarrow$ layk $\mathrm{k}^{\mathrm{h}}$-an-o- & "obtain" \\
\hline e-lip- & leip-o- & $\rightarrow$ limp-an-o- & "leave" \\
\hline e-mat ${ }^{\text {h}}-$ & [none] & $\rightarrow$ mant $^{\mathrm{h}}$-an-o- & "learn" \\
\hline
\end{tabular}




$$
\begin{aligned}
& \text { e-pat }{ }^{\text {h }} \quad \text { pask }^{\text {h }} \text {-o- } \rightarrow \text { pant }^{\text {h }} \text {-an-o- } \quad \text { "suffer" } \\
& \text { e-put }{ }^{\mathrm{h}}-\quad \text { peut }^{\mathrm{h}}-\mathrm{O}-\mathrm{p} \quad \rightarrow \text { punt }^{\mathrm{h}} \text {-an-o- } \quad \text { "inquire" } \\
& \text { e-p }{ }^{\mathrm{h}} \text { ug- } \quad \mathrm{p}^{\mathrm{h}} \text { eug-o- } \rightarrow \mathrm{p}^{\mathrm{h}} \text { ung-an-o- } \quad \text { "flee" }
\end{aligned}
$$

\subsection{Apparent counterexamples}

Thus far in §3, I have argued that Ancient Greek stem uniformity only arose in cases that can be analyzed as extension of an existing uniform pattern, and that the aorist was always the base of leveling. There are apparent counterexamples to this second claim: cases where the present serves or seems to serve as the base of leveling. Here I will treat two classes of counterexamples. ${ }^{18}$

The largest class of counterexamples is just comparable to those English strong verbs that are transferred into the regular weak class. A similar process is common in Greek: transfer from the class forming non-sigmatic aorist stems by root ablaut, into the class of sigmatic aorists. Two representative examples of this transfer are shown in (17).

$\begin{array}{llll}\text { Present stem } & \text { Earlier aorist stem } & \text { New aorist stem } & \\ \text { ag-o- } & \text { ēgag- (/e-agag-/) } & \rightarrow \text { èks- (/e-ag-s-/) } & \text { "lead" } \\ \text { leip-o- } & \text { e-lip- } & \rightarrow \text { e-leip-s- } & \text { "leave" }\end{array}$

The new aorist forms cited in (17) were at first sporadic but eventually became common or regular (Mandilaris 1973: 143-145). Such cases are clearly extension, with the present, not the aorist, serving as the pivot. ${ }^{19}$

To understand why this transfer type goes against the directionality pattern of other changes (where aorists serves as pivots), it is important to realize that the great majority of Ancient Greek verbs have thematic present stems and sigmatic aorists; an example is "send" (present stem pemp-o-, aorist e-pemp-s-). Since classes with many members tend generally to draw other items into them, there was an independent pressure on

\footnotetext{
${ }^{18}$ For a third class of counterexamples I have no account. In some dialects other than Attic, the original $k-z d$ alternation in (12b) was extended to new verbs, whose original aorist stems were replaced by stems in -k-s-. For example, in Cretan (Bile 1988: 219-221), based on present psaphizd-o- "count", aorist $e$ pse $p^{h}$ is- was replaced by e-psap ${ }^{h} i k-s-$.

${ }^{19}$ Note that the paradigm of "leave" (present leip-o-, aorist $e$-lip-) generated both the new present in (16) and the new aorist in (17); the extension in (16) was earlier (attested in early Greek poetry) and the shift in (17) was later (attested in the comic poet Aristophanes and then only in much later sources).
} 
verbs to fall into the class with thematic present stems and sigmatic aorists. Most of the transfers shown above - (9-10), (11b), (12b), (13), (15b) - are in fact of precisely this type. But in all those other cases, the initial paradigm had a sigmatic aorist on the basis of which a new present stem could be formed. The exceptional pattern in (17) involves verbs which had no sigmatic aorist to begin with.

In short, there is no way of transferring a root like "lead" or "leave" in (17) into the relevant large target class except by generating a new sigmatic aorist stem based on the present. Aorist stems like égag- and e-lip- themselves fall into no patterns that would generate a new present stem. The broader generalization is that the otherwise prevalent directionality patterns in a language fail just in case the only possible transfer demands an unexpected pivot. ${ }^{20}$

A second apparent counterexample to the generalization that Ancient Greek aorists rather than presents are pivots of extension and leveling involves Grassmann's Law. This was a sound change which had the effect of deaspirating the first of two successive aspirated stops in a root. For example, from a root $t^{h} t^{h} i k^{h}$ - "hair", nom. sg. $t^{h} r i k s$ shows regular deaspiration ( ${ }^{*} k^{h} s>k s$ ) before nom. sg. $-s$ while gen. sg. trik ${ }^{h}$ s shows the effect of Grassmann's Law.

Grassmann's Law alternations were retained in nouns, as just indicated, and in some verbs, but they were leveled in other verb paradigms. As seen in (18), this affected the aorist and future stems of three verbs.

$$
\begin{aligned}
& \text { Present stem Aorist stem } \quad \text { Future stem } \\
& \text { peit }{ }^{\mathrm{h}} \text {-o- } \quad \text { *e-p }{ }^{\mathrm{h}} \text { eis- } \rightarrow \text { e-peis- } \quad * \mathrm{p}^{\mathrm{h}} \text { eis- } \rightarrow \text { peís-o- } \quad \text { "persuade" } \\
& \text { peut }{ }^{\mathrm{h}} \text {-o- e-put }{ }^{\mathrm{h}} \text { - "p } \mathrm{p}^{\mathrm{h} e u ́ s-} \rightarrow \text { peús-o- "learn" }
\end{aligned}
$$

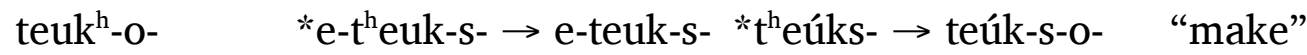

Note that leveling seems to favor the present stem in each case.

In this apparently exceptional case, however, there is clear evidence that the pivot

\footnotetext{
${ }^{20}$ For example, in Latin nominal paradigms, the usual directionality of leveling was (as is also common crosslinguistically) that the nominative influenced non-nominative forms. Against this generalization, the famous leveling of nom. sg. honōs "honor", gen. sg. honōris (honōs $\rightarrow$ honor) was a transfer into the class of soror "sister", gen. sg. sorōris. The shifting class was small; the model class was large and full of frequent and productive members, and crucially the only point of contact between the two paradigms was outside the nominative. Similarly, in the Greek case, the point of contact between the two paradigms is outside the aorist.
} 
of the change was not in fact the present stem at all but another form elsewhere in the paradigm: the perfect middle. For the leveling in (18) happened only in those paradigms with a perfect middle whose forms also underwent Grassmann's law. This is shown in (19), where the perfect middle participles are given in the form they would have had prior to a set of consonant $+m$ assimilations.

$$
\begin{aligned}
& \text { Present stem Perfect middle participle Aorist or future stem } \\
& \text { peit }{ }^{\mathrm{h}} \text { - *pe-peit }{ }^{\mathrm{h}} \text {-ménos } \quad \text { *e-peis- } \rightarrow \text { e-peis- } \\
& \text { peut }{ }^{\mathrm{h}} \text { - *pe-peut }{ }^{\mathrm{h}} \text {-menos } \quad \mathrm{p}^{\mathrm{h}} \text { eus- } \rightarrow \text { peus- } \\
& \text { teuk }{ }^{\mathrm{h}} \text { - *te-teuk }{ }^{\mathrm{h}} \text {-ménos *e-t }{ }^{\mathrm{h}} \text { euk-s- } \rightarrow \text { e-teuk-s- }
\end{aligned}
$$

Perfect middle forms like *pepeit ménos ( $<{ }^{*} p^{h} e p^{h} e i t^{h} m e ́ n o s$ ) in (19) also show the effects of Grassmann's Law.

By contrast, as seen in (20), there was no leveling of Grassmann's Law alternations in paradigms without a perfect middle.

(20) a. Present stem $e k^{h}-e / o$ - 'have' < "hek $k^{h}$ with Grassmann's Law

Aorist stem $e$-sk ${ }^{h}$

Future stem hek-s-e/o-

Perfect middle: defective

b. Present stem trek $k^{h}-e / o$ - "run" $<* t^{h} r e k^{h}$ - with Grassmann's Law

Future stem: $t^{\text {h }}$ reks-e/o-

Aorist stem: suppletive!

Perfect middle: suppletive!

There was also no leveling if the perfect middle underwent a $-p^{(h)} m->-m m$ - assimilation. This is shown by the example in (21). ${ }^{21}$

(21) Present stem $t^{2} p^{h}-e / o-$ "nourish" $<{ }^{*} t^{h} r e p^{h}-e / o$ - with Grassmann's Law

Aorist stem $e-t^{h} r e p-s-$

Future stem $t^{h}$ rep-s-e/o-

Perfect middle participle te-t $t^{h} r a ́ m-m e n o s$

The significant contrast here is between the verbs in (20-21), which retained alterna-

\footnotetext{
${ }^{21}$ I assume that the $-p^{(h)} m->-m m$ - assimilation in (21) preceded the changes that eventually happened in the perfect middle forms in (19): $-t^{(h)} m->-s m$ - and $-k^{(h)} m->-y m$-. This is a reasonable assumption given that $-p^{(h)} m$ - clusters survive nowhere, in any position, in any Greek dialect after 1200 BCE. In the earlier Mycenaean dialect, neither assimilation had happened.
} 
tions created by Grassmann's Law, and those in (18-19), which leveled them. Between these two sets of verbs the only meaningful difference is that the verbs in (18-19) had perfect middle forms that underwent Grassmann's Law. In the literature on Greek historical morphology, it is well established that the perfect middle played a pivotal, influential role in the evolution of many patterns (Chantraine 1961); the case at hand is thus simply another example.

\subsection{Summary}

I now summarize the two main arguments of this section. First, present-aorist stem alternations were leveled in Ancient Greek only if a model uniform paradigm existed to served as the analogical basis, never in contexts lacking such models. This is contrary to the prediction of the view that uniformity is a target of change, that a desire for uniform paradigms somehow drives language change. Second, against the characteristic pattern of English and many other languages, the aorist rather than the present stem regularly served as the pivot in cases of extension and leveling. If directionality is an effect of "markedness", then the aorist rather than the present is the "unmarked" Ancient Greek aspectual category.

$4 \quad$ Directionality and the origin of markedness

Why did a non-present form (the aorist) serve as the basis for leveling in Ancient Greek, when in English and other languages it is always the present that plays this role? Here a brief survey of theories of directionality may be useful. Many authors have discussed the phenomenon, and several proposals exist to account for the attested patterns. Three of these are essentially morphophonological. For example, Schindler (1976) argued that directionality patterns can be sensitive to the type of opacity of a phonological pattern being leveled or extended. Barr (1994) appealed to morphophonological idiosyncrasy in general; more recently, Albright (2003, 2005, this volume) has argued that the base in analogical change is, or is determined from, a surface form from which other surface forms can most effectively be predicted. None of these accounts based on morphophonological patterns readily explains the Ancient Greek data; Greek presents in particular belong to more morphological subpatterns than aorists, and thus presents are relatively hard to predict from the forms of their aorists. 
The most common account of directionality effects appeals to frequency: the base is the most frequent form. This view was classically expressed by Verner (1875), Paul (1880), Wheeler (1887), and other authors, and is more recently associated with Bybee (e.g. 2001). Indeed, to explain the pattern in which the present is the base of analogical changes, it has been noted that presents are more common than non-presents. However, according to Duhoux (1992: 502-503), the text frequency of Ancient Greek tense/aspect forms is as shown in (22) for indicative and non-indicative verbs. ${ }^{22}$

$$
\begin{aligned}
& \text { Indicative (49\% of total) } \\
& \text { Present + Imperfect: } 55 \%
\end{aligned}
$$

Present: $23 \%$

Imperfect: $32 \%$

\section{Non-indicative ( $51 \%$ of total)}

Present: 49\%

Aorist: $40 \%$

Other: $10 \%$

Aorist: $34 \%$

Other: $11 \%$

The base of paradigmatic extensions and leveling in Greek, the aorist, is therefore not the most frequent form (34-40\% aorist vs. $49-55 \%$ present).

Another approach to directionality is that of Jerzy Kuryłowicz, who wrote that '[s]o-called "analogical" actions follow the direction: formes de fondation $\rightarrow$ formes fondées, whose relationship emerges from their spheres of usage' (1945-49: 23). Later expanding on this idea, he wrote the following (Kuryłowicz 1964: 37-39):

In order that a proportion $a: b=c: d \ldots$ be valid and correct, the relation between $a$ and $b, c$ and $d$, must be shown to be a relation between basic and founded form ... [This relation] is due to the respective ranges of occurrence [= spheres of usage] of $a$ and $b, a$ being both neutral and negative, $b$, positive. This means that $a$ is used also (as a neutral member) outside the opposition $a$ (negative) $: b$ (positive). Such is the normal relation ... e.g. between Latin lupus (neutral use $=$ without distinction of sex; negative use $=$ male) : lupa (positive use $=$ female).

On this approach, it would be necessary to say that the English present is the 'neutral'

\footnotetext{
${ }^{22}$ Duhoux's statistics are based on earlier studies of a range of authors. Of course it can be objected that frequencies in surviving texts are not the same as the real-life frequencies that language users would have been exposed to; but the surviving texts do include colloquial as well as other texts and a difference of $10-15 \%$ is in any case not trivial.
} 
member of the present-preterite opposition and the Ancient Greek aorist is the 'neutral' member of the present-aorist opposition. Is there evidence to support this view? Does the Ancient Greek aorist have a broader 'range of occurrence' or 'sphere of usage' than the present?

I suggest that evidence of three types supports this view. First, in morphology, there are a few cases where a contrast between competing present forms is neutralized in the aorist. This is shown in (23).

$$
\begin{aligned}
& \text { Aorist Present I Present II ("durative") } \\
& \text { e-sk }{ }^{\mathrm{h}}-\quad \quad \mathrm{ek}^{\mathrm{h}}-\mathrm{O}-<{ }^{*} \text { sek }^{\mathrm{h}}-\mathrm{o}-\quad \text { isk }{ }^{\mathrm{h}}-\mathrm{o}-<{ }^{*} \text { si-sk }{ }^{\mathrm{h}} \text {-o- "have, hold" } \\
& \text { e-mein- men-o- mi-mn-o- "stay, stand fast" } \\
& \text { e-trō-s- trō-o- ti-trō-sk-o- "kill, damage" } \\
& \text { e-kale-s- kale-o- ki-klēsk-o- "call" }
\end{aligned}
$$

To be sure, relatively few verbs retain the archaic pattern shown here.

In semantics there is additional relevant evidence of two types. One concerns what is traditionally called 'markedness' (what Haspelmath 2006 calls 'semantic markedness', i.e. the phenomenon of interest to Kuryłowicz). In discussing the Russian perfective-imperfective aspectual contrast, Filip (2000: 82-83) comments as follows (cf. Jakobson 1932): 'Since imperfective verbs can be used to denote total (or complete) events, that is, with the same function as perfective verbs, in traditional and structuralist Slavistics they are considered to be the unmarked member in the aspectual opposition.'

The Ancient Greek aorist has likewise been said to be the 'marked' member of the present-aorist opposition because, in the present, the imperfective-perfective contrast is 'completely neutralized' (Duhoux 1992: 48). But this view is incorrect, since in suitable aspectual contexts, as illustrated in (24), aorists may refer to the here and now. ${ }^{23}$

(24) a. éblc

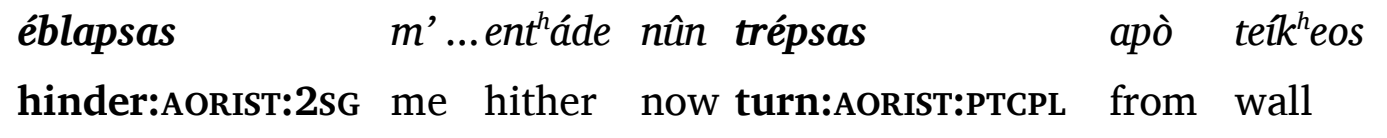

"You hinder me ... in now turning (me) hither from the wall."

(Iliad 22.15-16)

\footnotetext{
${ }^{23}$ Grammatical abbreviations appearing in the Greek examples in (24-27) include IMPF (imperfect), INF (infinitive), NEG (negative), PTCL (discourse particle), PTCPL (participle), sUBJ (subjunctive), and wH (question word).
} 
b. mēdén ti lían dusp ${ }^{h}$ oreîn parèinesa

NEG at.all very.much be.angry:INF advise:AORIST:1sG

"I advise (you) not to be too angry." ～(Euripides Andromache 1234)

c. tí et aúmasas?

WH be.surprised:AORIST:2sG

"Why are you surprised?"

(Aristophanes Clouds 185)

Moreover, the aorist is not only possible in the here-and-now context of the present, but it is in fact 'preferred when ... the author shows no particular interest in the verbal action, and he renders it in the most banal possible way from the aspectual point of view' (Duhoux 1992: 378). That is, just as Kuryłowicz's Latin masculine lupus 'wolf' can refer to a female wolf or wolves in general, while feminine lupa cannot refer to a male wolf or wolves in general, so the aorist can be used in the here-and-now temporal context of the Ancient Greek present.

The final argument concerns negation. It is a well-known feature of Ancient Greek that while positive imperatives are present or aorist according to the aspectual context, negative ('prohibitive') imperatives are aorist, as illustrated in (25).

$$
\begin{array}{ll}
\text { mè katà toùs nómous dikásēte ... } \\
\text { NEG according.to the laws judge:AORIST:SUBJ:2PL }
\end{array}
$$

"Do not judge according to your laws ..."

(Demosthenes 21.211)

In other words, the present-aorist contrast is regularly neutralized in this modal context.

A similar neutralization is seen in non-imperative negative contexts. As Gildersleeve (1900: 106) wrote, '[t]otal negation is expressed by the aorist.' The infinitives in (26) are coordinated and generally comparable, for example, but the negated infinitive is aorist while the other is imperfect (the aspectual context is imperfective).

$$
\begin{array}{lllll}
\text { mēdèn hamarteîn esti theôn kaì pánta katorthoûn } & \\
\underline{\underline{\mathrm{NEG}}} \text { err:AORIST:INF be:3SG } & \text { of.gods and all do.right:INF }
\end{array}
$$

"Not to err and to do all things right is for the gods."

(Demosthenes 18.289)

Two further examples contrasting negation with imperfects (past tenses of the present) and aorists appear in (27a-b); both translations are by Gildersleeve (1900: 95). 
(27) a. hoi mèn ouk êlthon,

the PTCL NEG come:AORIST:3PL

hoi d' elthóntes oudèn epoíoun

the PTCL come:AORIST:PARTICIPLE NEG do:IMPF:3PL

"Some did not come, and those who did come would not do anything."

(Demosthenes 18.151)

b. ouk anébain' epì tè̀n naûn

NEG go.up:IMPF:3sG on the ship

"He would not go on board the ship [as was expected]."

(Demosthenes 21.163)

The meaning of the negated imperfect in both examples is that an event continued not to take place, rather than that it did not take place (or did not continue to take place). As schematized in (28), imperfective aspect has scope over negation while simple negation is expressed with the aorist.

(28) a. 'did not come' in (27a) = NOT (come)

b. 'would not board the ship' in (27b)

$=$ IMPERFECTIVE (NOT (board the ship) )

In short, semantic (and some morphological) evidence suggests that the Ancient Greek aorist-present relationship is semantically monotonic - in other words, that imperfective-aspect (present, imperfect) forms add a component of meaning to perfectiveaspect (aorist) forms. I suggest that this semantic monotonicity lies behind the pattern of directionality seen in the extension and leveling of Greek stem alternations. Of course this in turn requires explanation - an appeal to 'markedness' would beg the question - and two approaches suggest themselves. One would appeal to universal (or innate) preferences. For example, a basic preference for semantically monotonic morphological derivations might guide word formation and so attested patterns of change.

An alternative view within usage-based models of morphological change (Barr 1994; Bybee 1985, 2001) might appeal to salience as a crucial factor determining patterns of change. Assuming (as in \$1) that new forms arise when existing forms are not learned, remembered, or accessed fast enough, a form should be more vulnerable to replacement if it is less salient in memory and so less readily accessed than one derived by the morphological system. Known causes of salience include morphophonological 
irregularity (Paul 1880, Barr 1994, Garrett 2007) and high token frequency. We may hypothesize, likewise, that morphological categories with a broader sphere of usage (or less complex meaning) are more salient in memory, hence more easily accessed in language production, and hence serve as bases in the derivation of new forms. ${ }^{24}$

The choice between these two approaches, both of them obviously speculative and sketchy as stated here, returns us to the main theme of this volume. To what extent are patterns of change themselves consequences of built-in linguistic (or psychological) preferences? To what extent do they simply reflect the interaction of independent mechanisms? For the case at hand - directionality effects in extension and leveling the answer is not yet known, but I have suggested that it will emerge from an understanding of the relation between morphology and semantics in language change.

\section{$5 \quad$ Conclusion}

I have made two main arguments in this chapter. First, I have shown that pure leveling does not exist and that the emergence of paradigm uniformity is always the imposition of an existing (uniform) pattern on a non-uniform paradigm. I conclude that paradigm uniformity is not an independent force or target in language change, for if a preference for uniform paradigms were an independent force, we should see clear evidence for it somewhere among the almost limitless variety of attested changes. This in turn bears on the general theme of this volume: paradigm uniformity, a common pattern in language, is diachronically epiphenomenal and not somehow embedded in universal grammar.

Second, I have identified a systematic difference between English and Ancient Greek in the directionality of paradigmatic changes. In English (and other languages), present-tense verb forms influence preterites; in Ancient Greek, presents are influenced by non-presents (aorists). I argued that this finding is not readily accommodated by theories invoking frequency or form predictability as the major factors influencing paradigmatic directionality, and that we need a more complex theory that also takes account of the semantics of morphological categories. Formulating such a theory more

\footnotetext{
${ }^{24}$ Susanne Gahl calls my attention to psychological studies (e.g. Hino \& Lupker 1996) showing that some lexical decision and naming tasks are done faster for polysemous words than monosemous words; it is possible that this effect is related to the sphere-of-usage patterns under discussion.
} 
precisely and modeling the interaction of all of the factors that contribute to morphological change remain exciting projects for the future.

\section{References}

Albright, Adam (2003). "Base selection in analogical change in Yiddish", in Julie Larson and Mary Paster (eds.), Proceedings of the Twenty-Eighth Annual Meeting of the Berkeley Linguistics Society, February 15-18, 2002, pp. 1-13. Berkeley, Calif.: Berkeley Linguistics Society.

Albright, Adam (2005). "The morphological basis of paradigm leveling", in Laura J. Downing, T. A. Hall, and Renate Raffelsiefen (eds.), Paradigms in phonological theory. Oxford: Oxford University Press, 17-43.

Anderson, Stephen R. (1977). "On mechanisms by which languages become ergative", in Charles N. Li (ed.), Mechanisms of syntactic change. Austin: University of Texas Press, 317-363.

Aristar, Anthony Rodrigues (1991). "On diachronic sources and synchronic patterns: An investigation into the origin of linguistic universals", Language 67: 1-33.

Barnes, Jonathan (2006). Strength and weakness at the interface: Positional neutralization in phonetics and phonology. Berlin: Mouton de Gruyter.

Barr, Robin (1994). A lexical model of morphological change. Ph.D. dissertation, Harvard University.

Benua, Laura (2000). Phonological relations between words. New York: Garland.

Bile, Monique (1988). Le dialecte crétois ancien. Paris: Paul Geuthner.

Blevins, Juliette (2004). Evolutionary phonology: The emergence of sound patterns. Cambridge University Press.

Blevins, Juliette (2005). "Understanding antigemination: Natural or unnatural history", in Zygmunt Frajzyngier, David Rood, and Adam Hodges (eds.), Linguistic diversity and language theories. Amsterdam: Benjamins, 203-234.

Blevins, Juliette, and Andrew Garrett (1998). “The origins of consonant-vowel metathesis”, Language 74: 508-556.

Blevins, Juliette and Andrew Garrett (2004). "The evolution of metathesis", in Bruce Hayes, Robert Kirchner, and Donca Steriade (eds.), The phonetic basis of phonology. Cambridge: Cambridge University Press, 117-156.

Buckley, Eugene (1999). "Uniformity in extended paradigms", in Ben Hermans and Marc van Oostendorp (eds.), The derivational residue in phonological optimality theory. Amsterdam: Benjamins, 81-104.

Burzio, Luigi (1996). "Surface constraints vs. underlying representation", in Jacques Durand and Bernard Laks (eds.), Current trends in phonology: Models and methods. Manchester: European Studies Research Institute, University of Salford, 123-142.

Burzio, Luigi (2000). "Segmental contrast meets output-to-output faithfulness", The Linguistic Review 17: 367-384.

Bybee, Joan L. (1985). Morphology: A study of the relation between meaning and form. Amsterdam: Benjamins.

Bybee, Joan L. (1988). "The diachronic dimension in explanation", in John A. Hawkins (ed.), Explaining language universals. Oxford: Blackwell, 350-379.

Bybee, Joan L. (2001). Phonology and language use. Cambridge: Cambridge University Press.

Bybee, Joan L.; Revere Perkins; and William Pagliuca (1994). The evolution of grammar: Tense, aspect, and modality in the languages of the world. Chicago: University of Chicago Press. 
Chantraine, Pierre (1961). Morphologie historique de la langue grecque. Paris: Klincksieck.

Croft, William (2000). Explaining language change: An evolutionary approach. Harlow, Essex: Longman.

Duhoux, Yves (1992). Le verbe grec ancien: Élements de morphologie et de syntaxe historiques. Louvain-laNeuve: Peeters.

Filip, Hana (2000). "The quantization puzzle", in Carol Tenny and James Pustejovsky (eds.), Events as grammatical objects: The converging perspectives of lexical semantics and syntax. Stanford, Calif.: CSLI Publications, 39-96.

Garrett, Andrew (1990a). “The origin of NP split ergativity”, Language 66: 261-96.

Garrett, Andrew (1990b). "Applicatives and preposition incorporation”, in Katarzyna Dziwirek, Patrick Farrell, and Errapel Mejías-Bikandi (eds.), Grammatical relations: A cross-theoretical perspective. Stanford, Calif.: Center for the Study of Language and Information, 183-98.

Garrett, Andrew (2001). "Reduplication and infixation in Yurok: Morphology, semantics, and diachrony", International Journal of American Linguistics 67: 264-312.

Garrett, Andrew (2007). "Paradigmatic heterogeneity", manuscript, University of California, Berkeley; to appear in a volume on analogy edited by Jim Blevins and Juliette Blevins.

Gildersleeve, Basil Lanneau (1900). Syntax of classical Greek from Homer to Demosthenes. New York: American Book Company.

Good, Jeffrey C. (2003). Strong linearity: Three case studies towards a theory of morphosyntactic templatic constructions. Ph.D. dissertation, University of California, Berkeley.

Guion, Susan (1998). "The role of perception in the sound change of velar palatalization", Phonetica 55: 18-52.

Haspelmath, Martin (1999a). "Optimality and diachronic adaptation", Zeitschrift für Sprachwissenschaft 18: 180-205.

Haspelmath, Martin (1999b). "Explaining article-possessor complementarity: Economic motivation in noun phrase syntax", Language 75: 227-243.

Haspelmath, Martin (2002). Understanding morphology. London: Arnold.

Haspelmath, Martin (2006). "Against markedness (and what to replace it with)", Journal of Linguistics 42: 25-70.

Hino, Yasushi, and Stephen J. Lupker (1996). "Effects of polysemy in lexical decision and naming: An alternative to lexical access accounts", Journal of Experimental Psychology: Human Perception and Performance 22: 1331-1356.

Hock, Hans Henrich (1991). Principles of historical linguistics. 2nd ed. Berlin: Mouton de Gruyter.

Hock, Hans Henrich, and Brian D. Joseph (1996). Language history, language change, and language relationship: An introduction to historical comparative linguistics. Berlin: Mouton de Gruyter.

Jakobson, Roman (1932). "Zur Struktur des russischen Verbums", in Charisteria Guilelmo Mathesio quinquagenari a discipulis et circuli linguistici Pragensis sodalibus oblata. Pragae: Sumptibus "Prazsky Linguisticky Krouzek", 74-84.

Jespersen, Otto (1942). A modern English grammar on historical principles, Part VI: Morphology. London: George Allen \& Unwin.

Kavitskaya, Darya (2002). Compensatory lengthening: Phonetics, phonology, diachrony. New York: Routledge.

Kenstowicz, Michael (1996). "Base-identity and uniform exponence: Alternatives to cyclicity”, in Jacques Durand and Bernard Laks (eds.), Current trends in phonology: Models and methods. Manchester: Euro- 
pean Studies Research Institute, University of Salford, 363-393.

Kiparsky, Paul (1972). "Explanation in phonology", in Stanley Peters (ed.), Goals in linguistic theory. Englewood Cliffs, N.J.: Prentice-Hall. Reprinted in Explanation in phonology (Dordrecht: Foris, 1982), chapter 5.

Kiparsky, Paul (1992). “Analogy”, International encyclopedia of linguistics, ed. by William Bright, s.v. New York: Oxford University Press.

Krygier, Marcin (1997). From regularity to anomaly: Inflectional i-umlaut in Middle English. (Bamberger Beiträge zur Englischen Sprachwissenschaft, 40.) Frankfurt am Main: Peter Lang.

Kuryłowicz, Jerzy (1945-49). "La nature des procès dits analogiques", Acta Linguistica 5: 15-37. [English translation with introduction by Margaret Winters, Diachronica 12 (1995) 113-45.]

Kuryłowicz, Jerzy (1964). The inflectional categories of Indo-European. Heidelberg: Carl Winter.

Luick, Karl (1914-1940). Historische Grammatik der englischen Sprache. 2 vols. Stuttgart: B. Tauchnitz.

Mandilaras, Basil G. (1973). The verb in the Greek non-literary papyri. Athens: Hellenic Ministry of Culture and Sciences.

Marckwardt, Albert H. (1935). "Origin and extension of the voiceless preterit and the past participle inflections of the English irregular weak verb conjugation", in Essays and studies in English and comparative literature. (University of Michigan Publications, Language and Literature, 13.) Ann Arbor: University of Michigan Press, 151-328.

McCarthy, John (2005). "Optimal paradigms", in Laura Downing, Tracy Alan Hall, and Renate Raffelsiefen (eds.), Paradigms in phonological theory. Oxford: Oxford University Press, 170-210.

McMahon, April (2000). Change, chance, and optimality. Oxford: Oxford University Press.

Meier-Brügger, Michael (1992). Griechische Sprachwissenschaft. 2 vols. Berlin: de Gruyter.

Mossé, Fernand (1968). A handbook of Middle English. Translated by James A. Walker. Baltimore: Johns Hopkins Press.

Ohala, John J. (1981). "The listener as a source of sound change", in Carrie S. Masek, Roberta A. Hendrick, and Mary Frances Miller (eds.), Papers from the Parasession on Language and Behavior, Chicago Linguistic Society. Chicago: Chicago Linguistic Society, University of Chicago, 178-203.

Ohala, John J. (1993). "The phonetics of sound change", in Charles Jones (ed.), Historical linguistics: Problems and perspectives. London: Longman, 237-278.

Paul, Hermann (1880). Prinzipien der Sprachgeschichte. (5th ed. 1920.) Tübingen: Max Niemeyer.

Schindler, Jochem (1974). "Fragen zum paradigmatischen Ausgleich", Die Sprache 20: 1-9.

Schwyzer, Eduard (1953). Griechische Grammatik, vol. 1: Allgemeiner Teil; Lautlehre; Wortbildung; Flexion. München: C. H. Beck.

Sommerstein, Alan (1982). [Aristophanes] Clouds. Warminster: Aris \& Phillips.

Steriade, Donca (1999). "Lexical conservatism in French adjectival liaison effects", in J.-Marc Authier, Barbara E. Bullock, and Lisa Reed (eds.), Formal perspectives in Romance linguistics. Amsterdam: John Benjamins, 243-270.

Steriade, Donca (2000). "Paradigm uniformity and the phonetics/phonology boundary", in Janet Pierrehumbert and Michael B. Broe (eds.), Papers in laboratory phonology 5: Acquisition and the lexicon. Cambridge: Cambridge University Press, 313-335.

Tiersma, Peter Meijes (1982). "Local and general markedness", Language 58: 832-849.

Trask, R. L. (1996). Historical linguistics. London: Arnold.

Vennemann genannt Nierfeld, Theo (1972). "Rule inversion”, Lingua 29: 209-242. 
Verner, Karl (1875). “Eine Ausnahme der ersten Lautverschiebung”, [Kuhn's] Zeitschrift der vergleichende Sprachforschung 23: 97-130.

Wheeler, Benjamin Ide (1887). Analogy and the scope of its application in language. New York: J. Wilson.

Yu, Alan C. L. (2003). The phonology and morphology of infixation. Ph.D. dissertation, University of California, Berkeley. 